58. Turner B, Lin X, Calmon G, Roberts N, Blumhardt LD. Cerebral atrophy and disability in relapsing-remitting and secondary progressive multiple sclerosis over four years. Mult Scler 2003;9:21-27.

59. Fox NC, Jenkins R, Leary SM, et al. Progressive cerebral atrophy in MS: a serial study using registered, volumetric MRI. Neurology 2000; 54:807-812.

60. Molyneux PD, Kappos L, Polman C, et al. The effect of interferon beta-1b treatment on MRI measures of cerebral atrophy in secondary progressive multiple sclerosis. European Study Group on Interferon beta-1b in secondary progressive multiple sclerosis. Brain 2000;123: 2256-2263

61. Amato MP, Bartolozzi ML, Zipoli V, et al. Neocortical volume decrease in relapsing-remitting $\mathrm{MS}$ patients with mild cognitive impairment. Neurology 2004;63:89-93.

Neuro/mages
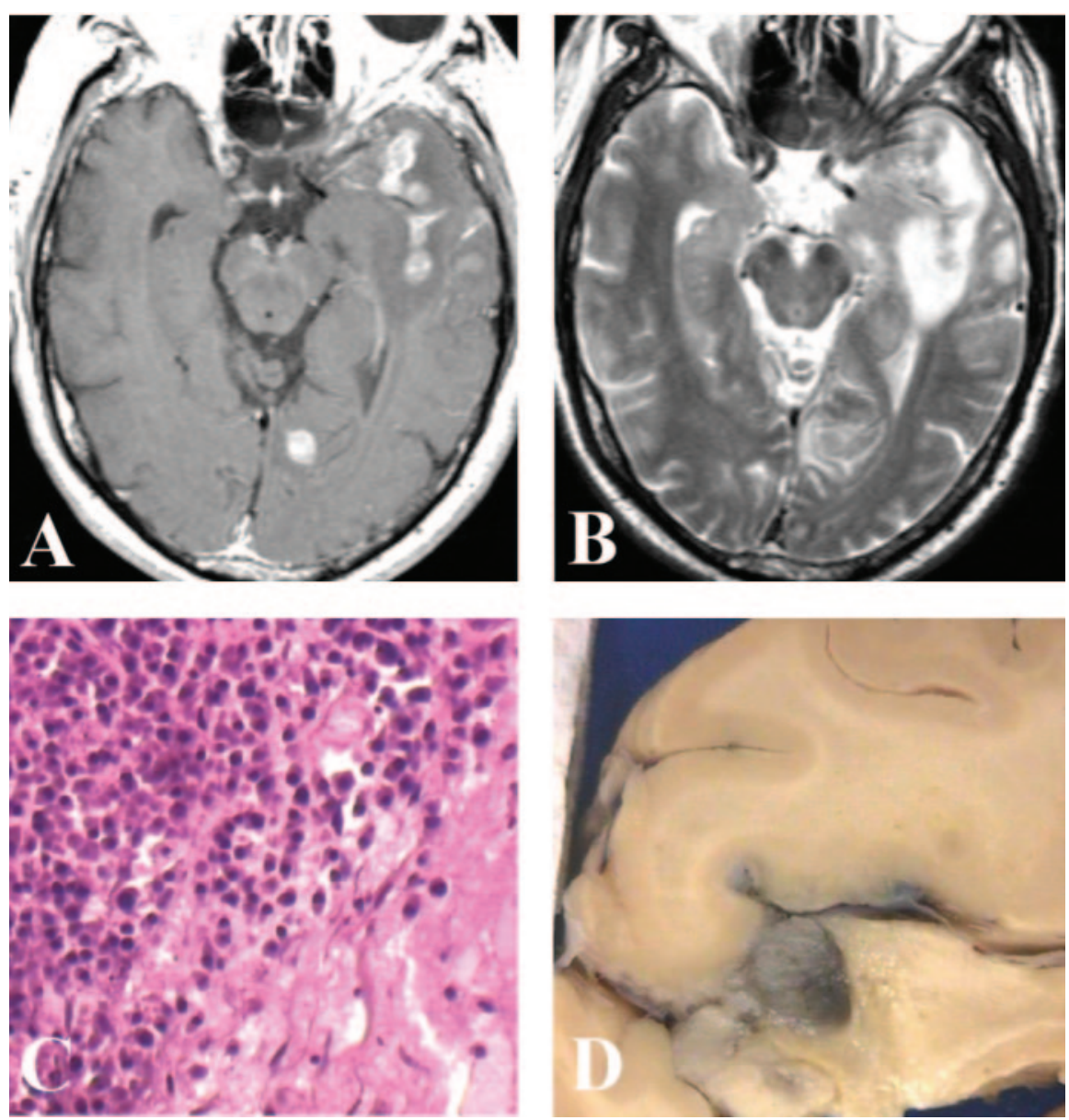

Figure. Post-contrast T1-weighted MRI of the brain shows multiple bilateral supra- and infratentorial enhancing lesions of the parenchyma, meninges, and oculomotor and trigeminal nerves (A). T2-weighted MRI shows the largest lesion involving left temporal lobe with surrounding edema (B). Microscopic $(C)$ and macroscopic (D) pathologic appearance of plasma cell metastases to brain.

\section{CNS myelomatosis}

Vitalie D. Lupu, MD; Nirmal Saini, MD; and Marshall Balish, MD, PhD, Washington, DC

A 62-year-old man with IgGк multiple myeloma (MM), who had been treated with autologous bone marrow transplant, presented with Herpes zoster ophthalmicus and mental state deterioration. Brain MRI raised suspicion of viral encephalitis (figure, A, B). CSF demonstrated a total protein of $225 \mathrm{mg} / \mathrm{dL}, 9$ red blood cells, and 24 white blood cells with $99 \%$ plasma cells. CNS myelo-

Address correspondence and reprint requests to Dr. Vitalie Lupu, EMG section, National Institute of Neurologic Disorders and Stroke, NIH, Bldg. 10, Room 5C101, 10 Center Drive MSC-1404, Bethesda, MD 20892-1404; e-mail: lupuv@ninds.nih.gov matosis, revealed by CSF cytology, led to the patient's death 3 weeks later. Postmortem neuropathologic examination of the brain (figure, C, D) confirmed MM metastases to leptomeninges, brain parenchyma, choroid plexus, and pineal cranial nerves III and V. CNS invasion by plasma cells is an unusual complication of MM, rarely encountered by neurologists. Its clinical and imaging features should be differentiated from those of viral encephalitis. ${ }^{1,2}$

Copyright $\odot 2005$ by AAN Enterprises, Inc.

1. Fassas AB, Muwalla F, Berryman $T$, et al. Myeloma of the central nervous system: association with high-risk chromosomal abnormalities, plasmablastic morphology and extramedullary manifestations. $\mathrm{Br} \mathrm{J}$ Haematol 2002;117:103-108.

2. Kennedy PG. Viral encephalitis: causes, differential diagnosis, and management. J Neurol Neurosurg Psychiatry 2004;75(suppl 1):110-15. 


\title{
Neurology
}

\author{
CNS myelomatosis \\ Vitalie D. Lupu, Nirmal Saini and Marshall Balish \\ Neurology 2005;64;1007 \\ DOI 10.1212/WNL.64.6.1007
}

This information is current as of March 21, 2005

\section{Updated Information \&}

Services

\section{Supplementary Material}

\section{References}

Permissions \& Licensing

Reprints including high resolution figures, can be found at: http://n.neurology.org/content/64/6/1007.full

Supplementary material can be found at: http://n.neurology.org/content/suppl/2007/04/02/64.6.1007.DC1

This article cites 2 articles, 1 of which you can access for free at: http://n.neurology.org/content/64/6/1007.full\#ref-list-1

Information about reproducing this article in parts (figures,tables) or in its entirety can be found online at:

http://www.neurology.org/about/about_the_journal\#permissions

Information about ordering reprints can be found online:

http://n.neurology.org/subscribers/advertise

Neurology ${ }^{\circledR}$ is the official journal of the American Academy of Neurology. Published continuously since 1951, it is now a weekly with 48 issues per year. Copyright . All rights reserved. Print ISSN: 0028-3878. Online ISSN: 1526-632X.

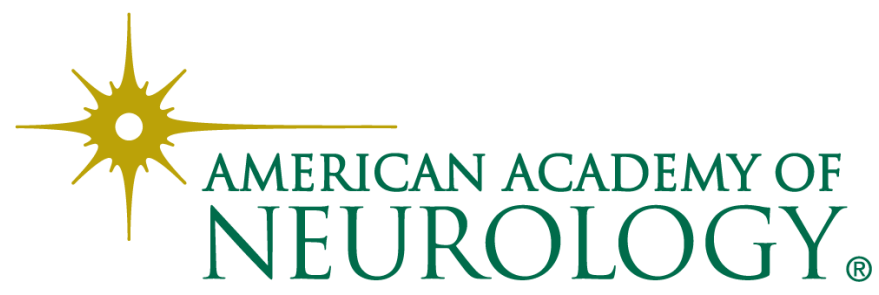

